\title{
Sampling Methodology of Alphitobius diaperinus (Coleptera: Tenebrionidae) Population in Poultry Houses
}

\author{
Daian Guilherme Pinto de Oliveira ${ }^{1 *}$ \\ https://orcid.org/0000-0002-4627-7086
}

\section{Rafael Freire Miguel $^{1}$}

https://orcid.org/0000-0003-4663-0262

\author{
Andrea Kusumota Bonini ${ }^{2}$ \\ https://orcid.org/0000-0002-4508-8400
}

\section{Luis Francisco Angeli Alves ${ }^{2}$ \\ https://orcid.org/0000-0002-3102-764X}

Received: 2018.03.18; Accepted: 2019.07.08.

\footnotetext{
${ }^{1}$ Federal University of Technology Paraná, Department of Biology, Santa Helena, Paraná, Brazil; '²Western Paraná State University, Agricultural Biotechnology Lab., Cascavel, Paraná, Brazil.

*Correspondence: daianguilherme@gmail.com; Tel.: +55-45-3268-8800 (D.G.P.O.)
}

\section{HIGHLIGHTS}

- A sampling method has been described and validated.

- The method can be used in tests of products to control $A$. diaperinus.

\begin{abstract}
This paper describes a methodology to evaluate Alphitobius diaperinus (Darkling beetle) population in order to estimate the effectiveness of control methods, consisting of direct sample collections from the poultry litter in 18 points, counting of adults and larvae, and subsequent comparison of the values obtained before and after of control strategies. It allows estimating the total population, population in a known area, as well to analyze the variations in different points all over the aviary. The method has shown to be very versatile, being indicated for population studies and efficacy evaluations, once it has already been validated in different experimental conditions.
\end{abstract}

Keywords: Lesser mealworm; Darkling beetle; Direct sampling.

\section{INTRODUCTION}

Alphitobius diaperinus (Panzer, 1797) (Coleoptera: Tenebrionidae), popularly known as lesser mealworm is a pest commonly found in litters of poultry houses, feeding on excrements, poultry food and dead fowls, being considered one of the main problems related to commercial poultry farming all over the world $[1,2]$. Larvae and adults are ingested by fowls as alternative to balanced poultry food, influencing the 
development of the latter, as well as being potential bird's pathogen vectors, especially for Salmonella spp. (Enterobacteriales: Enterobacteriaceae) [3,4,5].

The insect population sampling is an important tool in the study of ecology and in the correct implementation of control methods [6]. Few works were carried out to lesser mealworm population studies, both in Brazil and in other countries [7,8,9,10,11], making the sampling methodology a major difficulty when standardizing tests of control methods for this insect.

The main sampling study on poultry aviaries was conducted by [6], who proposed a direct sampling methodology, focusing on the main points of the pest occurrence. Such methodology proved to be suitable. However, depending on the population variation of the aviary, it may not be very effective in assessing the effectiveness of control strategies, because it does not consider points evenly distributed (resulting in high variation between samples), as well as it does not provide statistical tests for treatment comparisons, among other practical difficulties.

Thus, this study describes a methodology for evaluating the $A$. diaperinus population and its validation in experiments with pest control methods.

\section{MATERIAL AND METHODS}

The methodology described by [6] is to collect directly samples of litter in quadrants $(30 \times 30 \mathrm{~cm})$ spread over the entire length of the poultry house in 14 points (6 close to the pillars; 4 close to the small walls; 4 under the feeders), sieving the samples and counting the adults. The authors suggest collection of two samples; the first in the last week of the batch previous to the control method application, and the second in the last week of the batch that was stored after the application.

Seeking to improve and qualify the steps, changes in the methodology were made regarding number of sampling points and locations, consideration of subsamples, distinct counting of insects, number of evaluations, as well as changes in the analysis of the data obtained, also indicating the statistical analysis procedure.

Based on data obtained in the previous tests, a sequence of procedures for the new method was established. The aviary is divided into three areas (entrance, housing, back), distributing two points for sampling to each area, in the right and left side. Each point is a sample composed of three subsamples, taken directly by collecting from the litter in quadrants $(30 \times 30 \mathrm{~cm})$ in total depth till the soil, close to the pillar, in the small wall and under the feeders, totaling 18 points along the entire length of the aviary.

The samples are sieved, then stored in resistant plastic bags and kept at $-20^{\circ} \mathrm{C}$ for at least 48 hours. Then the insects are counted by distinguishing larvae and adults. An evaluation must be made in the last week of the batch before the application of control method (previous), another after applying and housing the fowls (post 1), and another in the last week of the batch that was stored after the application (post 2).

For analysis, the data obtained in the first evaluation will correspond to the entire population (100\%), and the following evaluations will indicate the percentage of reinfestation in comparison with the previous population. Due to the fact that the data belongs to a naturally non-uniform population, the treatment efficiency can be calculated by using Henderson \& Tilton's formula [12], comparing the data obtained among the aviaries over time by Mann-Whitney test $(P<0.05)$, and evaluating the values after control method applications in relation to the values before applying in each aviary, using Wilcoxon test $(P<0.05)$.

\section{RESULTS AND DISCUSSION}

The methodology here described (Figure 1), provides statistical accuracy for inferences about the data obtained, and, in addition, brings several advantages. It allows to evaluate all the aviary population directly and also by using distribution points, compare distinct aviaries, compare larval and adult population, and understand in a 
better way the population dynamics and the control method effect, due to the possibility of carrying out three evaluations.

It is believed that this standardization is of great importance. The method versatility and validation was supported, because it has been adequate in studies carried out with poultry to assess lesser mealworm control strategies, both with chemical [13] and biological insecticides [14], and also with inert powders [15].

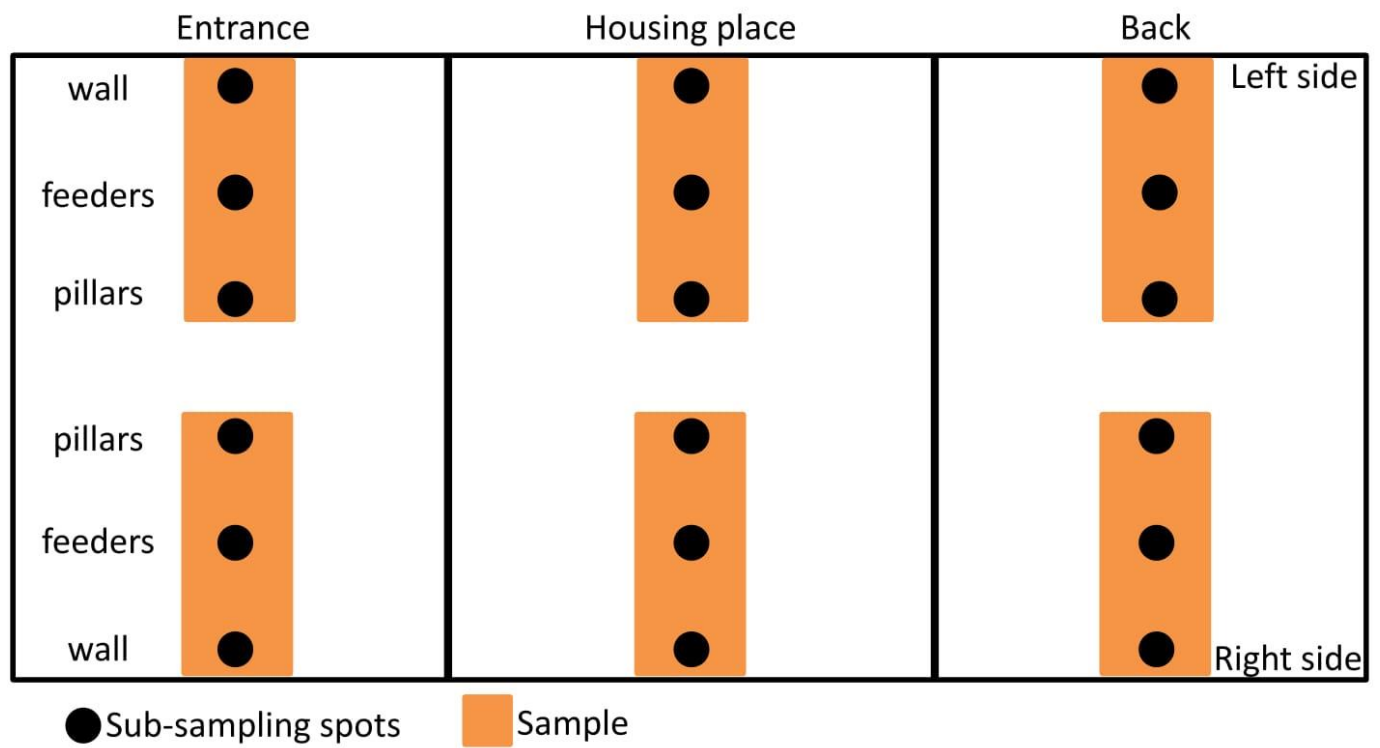

Figure 1. Diagram representing the population sampling methodology of Alphitobius diaperinus in aviaries

\section{REFERENCES}

1. Oliveira DGP, Alves LFA, Sosa-Gomez DR. Advances and perspectives of the use of the entomopathogenic fungi Beauveria bassiana and Metarhizium anisopliae for the control of arthropod pests in poultry production. Braz J Poultry Sci. 2014;16:1-12.

2. Japp AK. Influência do Aphitobius diaperinus (Panzer, 1797) (Coleoptera, Tenebrionidae) no desempenho zootécnico de frangos de corte e avaliação da terra de diatomácea como estratégia para o seu controle [master's thesis]. Curitiba (PR): Universidade Federal do Paraná; 2008. 58p.

3. Hazeleger WC, Bolder NM, Beumer RR, Jacobs-Reitsma WF. Darkling beetles (Alphitobius diaperinus) and their larvae as potential vectors for the transfer of Campylobacter jejuni and Salmonella enterica Serovar Paratyphi B Variant Java between successive broiler flocks. Appl Environ Microbiol. 2008;74:6887-91.

4. Crippen TL, Zheng L, Sheffield CL, Tomberlin JK, Beier RC, Yu Z. Transient gut retention and persistence of Salmonella through metamorphosis in the lesser mealworm, Alphitobius diaperinus (Coleoptera: Tenebrionidae). J Appl Microbiol. 2012;112:920-6.

5. Crippen TL, Sheffield CL, Beier RC, Nisbet DJ. The horizontal transfer of Salmonella between the lesser mealworm (Alphitobius diaperinus) and poultry manure. Zoonoses Public Health. 2018;65(1):23-33.

6. Godinho RP, Alves LFA. Métodos de avaliação de população de cascudinho (Alphitobius diaperinus) PANZER em aviários de frango de corte. Arq Inst Biol. 2009;76(1):107-10.

7. Salin C, Delettre YR, Cannavacciuolo M, Vernon P. Spatial distribution of Alphitobius diaperinus (Panzer) (Coleoptera: Tenebrionidae) in the soil of a poultry house along a breeding cycle. Europ J S Biol. 2000;36(2):107-15.

8. Uemura DH, Alves LFA, Opazo MU, Alexandre TM, Oliveira DGP, Ursi MV. Distribuição e dinâmica populacional do cascudinho Alphitobius diaperinus (Coleoptera: Tenebrionidae) em aviários de frango de corte. Arq Inst Biol. 2008;75(4):429-35. 
9. Pinto DM, Ribeiro PB, Bernardi E. Flutuação populacional de Alphitobius diaperinus (Panzer, 1879) (Coleoptera: Tenebrionidae), capturados por armadilha do tipo sanduíche, em granja avícola, no Município de Pelotas, RS. Arq Inst Biol. 2005;72(2):199-203.

10. Bicho CL, Almeida LM, Ribeiro PB, Silveira Junior P. Flutuação populacional circanual de coleópteros em granja avícola, em Pelotas, RS, Brasil. Iheringia, Ser Zool. 2005;95,20512.

11. Lopes WDZ, Costa FH, Lopes WCZ, Balieiro JC, Prado AP. Estudo da sazonalidade de Alphitobius diaperinus em criação de galinhas poedeiras por três diferentes métodos de coleta. Arq Inst Biol. 2006;73(2):195-202.

12. Henderson CF, Tilton EW. Test with acaricides against the brown wheat mite. J Econ Entomol. 1955;43(2):157-61.

13. Oliveira DGP, Cardoso RR, Mamprim AP, Alves LFA. Laboratory and field evaluation of a Cypermethrin-based insecticide for the control of Alphitobius diaperinus Panzer (Coleoptera: Tenebrionidae) and its in-vitro effects on Beauveria bassiana Bals. Vuill. (Hypocreales: Cordycipitaceae). Braz J Poultry Sci. 2016;18(3):371-80.

14. Alves LFA, Oliveira DGP, Lambkin T, Bonini AK, Alves VM, Pinto FGS, Scur MC. Beauveria bassiana applied to broiler chicken houses as biocontrol of Alphitobius diaperinus Panzer (Coleoptera: Tenebrionidae), an avian pathogens vector. Braz J Poultry Sci. 2015;17:459-66.

15. Oliveira DGP, Bonini AK, Alves LFA. Field assessments to control the Lesser Mealworm (Coleoptera: Tenebrionidae) using Diatomaceous Earth in poultry houses. J Econ Entomol. 2017;110:2716-23. BY NC) license (https://creativecommons.org/licenses/by-nc/4.0/). 